\author{
Agnieszka PAWŁOWSKA-KUBIK \\ Zakład Historii i Filozofii Nauk Medycznych \\ Wydział Nauk o Zdrowiu z Oddziałem Pielęgniarstwa i Instytutem Medycyny Morskiej i Tropikalnej \\ Gdański Uniwersytet Medyczny
}

\title{
Śmierć Stefana Jegomości króla polskiego w Grodnie 12 Decembra Anno Domini 1586 (Prawdziwa sprawa o chorobie i śmierci nieboszczyka Stefana Batorego króla polskiego) - źródło do losów Stefana Batorego i historii medycyny
}

Zarys treści: Tekst zawiera edycję dokumentu opisującego ostatnie dni życia Stefana Batorego oraz przeprowadzoną po śmierci króla sekcję zwłok. Dokument powstał tuż po zgonie Batorego w 1586 r., a jego autorem jest najprawdopodobniej Jakub Gosławski. Źródło opisuje dolegliwości monarchy oraz przebieg choroby, z uwzględnieniem zastosowanej przez królewskich medyków terapii. Oryginał dokumentu nie został odnaleziony, a dwie zachowane kopie znajdują się w Archiwum Głównym Akt Dawnych w Warszawie oraz w Bibliotece Czartoryskich w Krakowie. Niniejsza edycja porównuje odpisy, wykazując istotniejsze między nimi różnice, szczególnie w protokole sekcji zwłok.

\begin{abstract}
The text presents the edition of the document describing the last days of Stefan Batory's life and conducted after death of king post-mortem examination. The document was created right after the death of Batory in 1586, and Jakub Gosławski is most likely his author. The source describes ailments of the monarch and the course of disease, including therapy applied by royal physicians. The original of the document wasn't found, and two kept copies are in the Central Archives of Historical Records in Warsaw and at the Czartoryski Library in Cracow. This edition compares the copies, demonstrating important differences between them, especially discrepancies in the protocol of the post-mortem examination.
\end{abstract}

Słowa kluczowe: historia medycyny, medycyna nowożytna, Stefan Batory, choroby i dolegliwości królewskie, zgon króla, sekcja zwłok, Jakub Gosławski

Keywords: history of medicine, early-modern medicine, Stephan Batory, royal illnesses and afflictions, death of the king, post mortem examination, Jacob Gosławski

\section{Wstęp}

Dokument ukazujący ostatnie dni i godziny życia Stefana Batorego, funkcjonujący w rękopisach pt. Prawdziwa sprawa o chorobie i śmierci nieboszczyka Stefana Batorego króla polskiego lub Śmierć Stefana Jegomości króla polskiego w Grodnie 12 Decembra Anno Domini 1586, to źródło dla historyków nowożytnych, w szczególności zaś dla historyków medycyny, niezwykle cenne. Opisuje przebieg ostatnich dni życia drugiego elekcyjnego władcy Rzeczypospolitej Obojga Narodów, Stefana Batorego, nasilenie się objawów chorobowych, wreszcie śmierć i przeprowadzoną sekcję zwłok. Dość szczegółowe i wielowiekowe dociekania historyków i lekarzy przyczyn jego 
śmierci ${ }^{1}$ wynikały z dwóch zasadniczych powodów - śmierć władcy była nagła, a w powszechnej opinii uchodził on za człowieka zdrowego i w sile wieku², oraz pogłosek o otruciu monarchy³. Większość historyków uznaje dzisiaj niemal za pewnik przyjęty w pierwszej połowie XX w. pogląd, że Batory cierpiał na długotrwałą chorobę nerek, a przyczyną jego śmierci była ich niewydolność (mocznica, uremia) ${ }^{4}$. Za jedno z głównych źródeł do postawienia tej tezy posłużył właśnie prezentowany poniżej dokument. Jednocześnie zespół naukowców pod przewodnictwem Franciszka Waltera odrzucił wcześniejsze hipotezy, upatrujące przyczyny śmierci króla w apopleksji, chorobie serca czy powikłaniach wywołanych kiłą5. Nowsze badania podają jednak w wątpliwość przesądzoną, zdawałoby się tezę, o królewskiej mocznicy. Co istotne, wątpliwości owe wynikają nie tylko z postępu medycyny, jaki dokonał się w minionym czasie, ale oparte są również na ponownej, szczegółowej analizie tego źródła historycznego ${ }^{6}$.

Prawdziwa sprawa... doczekała się do tej pory pięciu wydań drukiem. Pierwszego z nich dokonał Edward Raczyński w 1830 r. ${ }^{7}$, drugie umieszczono w czasopiśmie „Wizerunki i Roztrząsania Naukowe" , trzecie w Zbiorze wiadomości do historyi sztuki lekarskiej w Polsce od czasów najdawniejszych aż do najnowszych autorstwa Ludwika Gąsiorowskiego9, czwarte, anonimowe, ukazało się w 1843 r. w czasopiśmie „Przyjaciel Ludu” ${ }^{10}$, piąte wreszcie, z 1849 r., jest dziełem Ignacego Żegoty Onacewi$\mathrm{cza}^{11}$. Żadna $\mathrm{z}$ dotychczasowych edycji nie jest jednak w pełni tożsama i zgodna $\mathrm{z}$ odpisami dokumentu

\footnotetext{
${ }^{1}$ Literatura na ten temat jest dość obszerna, rozpoczyna ją polemika dwóch królewskich medyków: Symoniusza i Bucelli: S. Simonius, D. Stephani primi Polonorum regis [...], sanitas, vita medica, aegritudo, mors, Nysa 1587; tenże, Amadei Curtii [...] Responsum ad Epistolam cuiusdam Georgii Chiakor, [b.m.w.] 1587; tenże, Responsum ad Refutationem scrippti de sanitate, [b.m.w.] 1588; tenże, Scopae quibus verritur Confutatio quam advocati Nicolai Bucellae... emiserunt, [b.m.w.] 1589; tenże, Appendix Scoparum, quae paulo ante in Nicolaum Bucellam Italum chirurgum antitrinitarum emissae sunt, Olomutii 1590; [M. Bucella], Epistola gen. d. Georgii Chiakor secretari ungari de morbo et obitu ser. magni Stephani regis, [b.m.w.] 1587; tenże, Confutatio responsi Simonis Simonii Lucensis ad epistolam Georgii Chiakor, Kraków 1588; tenże, Refutatio scripti Simonis Simonii, Kraków 1588; ale nowe głosy w dyskusji pojawiają się również w czasach nam bliższych: A. Pawiński, Zgon króla, „Tygodnik Ilustrowany”, 8, 1886, nr 206, s. 371-373; E. Wyrobek, Jaka była przyczyna tak szybkiej śmierci króla Stefana Batorego, „Ilustrowany Kurier Codzienny”, 16 XII 1929, dodatek: „Kurier Literacko-Naukowy”, s. 1-2; F. Giedroyć, Przyczyna zgonu króla Stefana Batorego, Przegl. Hist., 2, 1906, nr 1, s. 143-156; nr 2, s. 277-290; A. Knot, Dwór lekarski Stefana Batorego, „Archiwum Historii i Filozofii Medycyny oraz Historii Nauk Przyrodniczych”, 8, 1928, z. 2, s. 200-207; T. Jankowski, Śmierć Stefana Batorego w Grodnie, Grodno 1930, s. 13-22, 28-34; F. Walter, Choroby i zgon króla Stefana Batorego w świetle narady lekarskiej, „Polska Gazeta Lekarska”, 1934, nr 32, s. 595-598; nr 33/34, s. 609-610; nr 35, s. 633-636; T. Pragłowski, Choroby i śmierć króla Stefana Batorego w nowym naświetleniu, „Archiwum Medycyny Sądowej i Kryminologii”, 18, 1968, nr 1, s. 147-159; S. Szpilczyński, Sprzeczności renesansowej medycyny w świetle polemiki Simoniusza z Bucella po zgonie króla Stefana Batorego, „Archiwum Historii Medycyny”, 40, 1977, nr 3, s. 292-295; W. Dudziński, Choroba i śmierć króla Stefana Batorego, „Wiadomości Lekarskie”, 30, 1977, nr 24, s. 1923-1925; T. Marcinkowski, A New Appraisal of the Death Cause of King Stefan Batory, „Materia Medica Polona”, 23, 1991, nr 3, s. 233-235.

2 O tym m.in. wspominał kronikarz Reinhold Heidenstein; tenże, Dzieje Polski od śmierci Zygmunta Augusta do roku 1594 : ksiag XII, tłum. M. Gliszczyński, oprac. i wyd. J. Byliński, W. Kaczorowski, Opole 2015, s. 509.

${ }^{3}$ H.Z. Scheuring, Czy królobójstwo? Krytyczne studium o śmierci króla Stefana Wielkiego Batorego, Londyn 1964, s. 215-224; L. Szczucki, U źródet legendy o otruciu Stefana Batorego, w: Kultura staropolska - kultura europejska. Prace ofiarowane Januszowi Tazbirowi w siedemdziesiąta rocznicę urodzin, Warszawa 1997, s. 297-303.

${ }^{4}$ F. Giedroyć, Przyczyna zgonu, nr 1, s. 143-156, nr 2, s. 277-290; F. Walter, Choroby i zgon, nr 32, s. 595-598, nr 33/34, s. 609-610, nr 35, s. 633-636. Pogląd ten przyjął m.in. biograf Stefana Batorego, Jerzy Besala; tenże, Stefan Batory, Poznań 2010, s. 433.

${ }^{5}$ F. Giedroyć, Przyczyna zgonu króla Stefana Batorego, nr 2, s. 285-286; A. Pawiński, Zgon króla, s. 371-373; E. Wyrobek, Jaka byta przyczyna tak szybkiej śmierci, s. 1-2.

6 T. Pragłowski, Choroby i śmierć, s. 147-159; T. Marcinkowski, A New Appraisal, s. 233-235.

7 Prawdziwa sprawa o chorobie i śmierci króla Stefana, w: Pamiętniki do historyi Stefana króla polskiego, wyd. E. Raczyński, Warszawa 1830, s. 143-149.

8 „Wizerunki i Roztrząsania Naukowe”, poczet nowy, t. 9, (Wilno) 1836, s. 118-123.

${ }^{9}$ L. Gąsiorowski, Zbiór wiadomości do historyi sztuki lekarskiej w Polsce od czasów najdawniejszych aż do najnowszych, t. 1, Poznań 1839 , s. 284-287.

10 „Przyjaciel Ludu”, 1 VII 1843, R. 10, t. 1, s. 3-7.

${ }^{11}$ Panowanie Henryka Walezyusza i Stefana Batorego królów polskich z rękopisów Albertrandego podtug wydania Ż. Onacewicza. $Z$ dołączeniem pamiętników historyi Stefana Batorego dotyczących, Kraków 1849, s. 442-444.
} 
znajdującymi się dzisiaj w Archiwum Głównym Akt Dawnych w Warszawie oraz w Bibliotece Książąt Czartoryskich w Krakowie ${ }^{12}$.

Wydanie E. Raczyńskiego pomija niekiedy całe partie tekstu, które szczególnie z medycznego punktu widzenia są bardzo istotne. Przykładem tego jest chociażby opis narządów wewnętrznych króla sporządzony po sekcji zwłok (w szczególności dotyczy to nerek). Jednocześnie część akapitów i zwrotów, które wydają się być tożsame w rękopisach i wydaniu z 1830 r., w rzeczywistości różni się w istotnych szczegółach, np.: „,co ściągnęli z głowy” (rkps AGAD i rkps BCzart.) - „ściągali krew do głowy” (tekst Raczyńskiego). Skala różnic między rękopisem a wydaniem E. Raczyńskiego jest tak duża, że budzi wątpliwości, czy dla XIX-wiecznego wydawcy podstawą wydania był któryś z dokumentów znanych nam współcześnie (lub ich kopie), czy też posłużył się on innym, nieznanym bądź dziś już nieistniejącym rękopisem. Niestety E. Raczyński nie podał proweniencji źródła, które posłużyło mu za podstawę wydania tekstu. Wydanie drugie, trzecie i piąte to przedruki z opublikowanej przez niego edycji. Przedruki z 1836 i 1839 r. rzucają jednak nieco światła na źródło, z którego korzystał wcześniejszy wydawca. Zawierają mianowicie informację, że rękopis będący podstawą druku E. Raczyński zaczerpnął ze zbiorów po Abrahamie Cieświckim tudzież Cieświeckim (każda z wersji podaje inne wariant nazwiska właściciela rękopisu) ${ }^{13}$. Obecnie katalogi Biblioteki Raczyńskich w Poznaniu nie odnotowują istnienia zbiorów ani rękopisów pozostałych po szlachcicu o tym nazwisku. Różnice w obrębie tych czterech wydań dotyczą, z nielicznymi wyjątkami, niemal wyłącznie ortografii i interpunkcji.

Wydanie dokumentu z 1843 r., zatytułowane Śmierć Stefana JMci, króla polskiego, w Grodnie, 12 Decembr. 1586, jest najbardziej tajemnicze i jednocześnie najbardziej zbliżone do znanych nam rękopisów. Opublikowano je anonimowo w „Przyjacielu Ludu”, tygodniku poświęconym popularyzacji nauki, pierwszym magazynie ilustrowanym wydawanym na terenie zaboru pruskiego. Zamieszczano tam artykuły o charakterze historycznym, kulturalnym i krajoznawczym. Czasopismo wydawano w Lesznie w latach 1834-1849, jego wydawca był Ernest Günter, a redaktorem w czasie opublikowania omawianego źródła Józef Łukaszewicz, bibliotekarz Księgozbioru Raczyńskich ${ }^{14}$. Ponieważ to właśnie J. Łukaszewicz zamieszczał w periodyku artykuły historyczne i archeologiczne, prawdopodobne jest, że właśnie on opublikował także Śmierć Stefana JMci... Podobnie jak we wcześniejszych wydaniach, tutaj również nie podano proweniencji dokumentu, za wyjątkiem niewiele mówiącego dopisku: „Z współczesnego rękopismu". Obecnie katalogi Biblioteki Raczyńskich nie odnotowują istnienia dokumentu o tym tytule.

Tekst różni się natomiast znacząco od poprzednich wydań. Jest zbliżony do tekstów rękopisów będących podstawą niniejszej edycji, ale nie jest z nimi identyczny. Większość różnic powstało w wyniku pośpiechu i nieuwagi wydawcy. Nie odgrywają one kluczowej roli w analizie tekstu, np.: „na obiedzie” (rkps AGAD i rkps BCzart.) - „po obiedzie” (tekst w „Przyjacielu Ludu”); „,w czwartek” (rkps AGAD i rkps BCzart.) - „we wtorek” (tekst w „Przyjacielu Ludu”); „bolum” (rkps AGAD i rkps BCzart.) - „bulion” (tekst w „Przyjacielu Ludu”). Końcowy fragment opublikowanego w czasopiśmie tekstu wykazuje największe różnice w stosunku do obu rękopisów. Anonimowy przedruk zawiera fragment łacińskiego tekstu, który jest częścią testamentu króla (choć nie jest z rękopisem testamentu identyczny) ${ }^{15}$. Ani w rkps AGAD, ani w rkps BCzart. ten fragment tekstu nie występuje. Wygląda to, jakby wydawca tekstu w „Przyjacielu Ludu” niejako z rozpędu przepisał także wycinek kolejnego dokumentu. Jest to o tyle osobliwe, że łaciński tekst nie jest początkiem dokumentu Batorego, a jego końcową częścią.

12 „Śmierć Stefana Jegomości króla polskiego w Grodnie 12 Decembra A.D. 1586”, AGAD, Archiwum Radziwiłłów, dz. II, ks. 12, s. 766-768 [dalej: rkps AGAD]; „Prawdziwa sprawa o chorobie i śmierci nieboszczyka Stefana Batorego Króla Polskiego”, BCzart., Teka Naruszewicza, sygn. 91, s. 597-604 [dalej: rkps BCzart.].

${ }^{13}$ L. Gąsiorowski, Zbiór wiadomości do historyi sztuki lekarskiej, s. 287; „Wizerunki i Roztrząsania Naukowe”, poczet nowy, t. 9, (Wilno) 1836, s. 123.

${ }^{14}$ K. Jędrzejczyk, Tematyka archeologiczna w leszczyńskim „Przyjacielu Ludu”, „Acta Universitatis Lodziensis. Folia Archaeologica”, 24, 2004, s. 265-266; G. Wrona, Polskie czasopisma popularnonaukowe w XIX wieku. Ewolucja formy i treści, „Rocznik Historii Prasy Polskiej”, 10, 2007, nr 2, s. 12-13.

15 Por. AGAD, Archiwum Zamoyskich, sygn. 3041, s. 323. 
Więcej różnic wydanie z 1843 r. wykazuje w stosunku do rkps BCzart. Są to szczegóły, które jednak mają pewne znaczenie, np. „cisnąć palce” (rkps BCzart.) - „ciągnąć palce” (tekst w „Przyjacielu Ludu”); „nacierając” (rkps BCzart.) - „ścierając” (tekst w „Przyjacielu Ludu”). W wielu miejscach szyk zdania w tekście opublikowanym w 1843 r. jest inny niż w rkps BCzart., zdarza się, że pominięte są niektóre wyrazy. Nie zmienia to sensu wypowiedzi, ale zmusza do zastanowienia, czy rękopis wydano aż tak niestarannie, czy może anonimowy autor dysponował inną, niż nam znana, wersją dokumentu.

Niewątpliwie najmniej różnic wydanie z 1843 r. wykazuje w stosunku do rkps AGAD. Większość z nich nie odgrywa kluczowej roli w interpretacji tekstu (np.: „zakręciwszy szyję” w rkps AGAD „zakręciwszy się” w „Przyjacielu Ludu”; „podniósł” w rkps AGAD - „powiódł” w „Przyjacielu Ludu”). Warto natomiast zwrócić uwagę, że rozbieżności w zakresie interpunkcji w jednym miejscu tekstu powodują dwie różne możliwości odczytania fragmentu, w którym mowa o lokalizacji baniek stawianych Stefanowi Batoremu 11 grudnia: „dwie na prawej stronie pod łopatką i niżej, jedną na lewej stronie pod łopatką” (rkps AGAD) - „dwie na prawej stronie pod łopatką, a niżej jednę na lewej stronie pod łopatką” („Przyjaciel Ludu”). Niewielka liczba różnic pozwala na postawienie hipotezy, że znajdujący się w Radziwiłłowskim archiwum odpis lub inny, lecz z nim tożsamy, mógł być podstawą wydania dokumentu ogłoszonego na łamach „Przyjaciela Ludu”.

Za zasadnością ponownego wydania opisu ostatnich dni Stefana Batorego przemawia zatem kilka przesłanek. Przede wszystkim wszystkie dotychczasowe edycje pochodzą z pierwszej połowy XIX w., kiedy nie tylko nie istniała instrukcja regulująca zasady wydawania źródeł historycznych, ale brak było nawet ogólnych zaleceń dla potencjalnych edytorów. Część wydawców ingerowała w styl, ortografię czy zasady gramatyczne, podawała ogólnikowy opis dokumentu (bądź nie podawała go w ogóle), nie wymieniała nazw archiwów, z których dokumenty pochodziły, o sygnaturach już nie wspominając. Tak też było w przypadku źródła dotyczącego ostatnich chwil i zgonu Stefana Batorego. Przede wszystkim zaś rkps BCzart. nigdy chyba nie stał się podstawą żadnego z wydań, a jeśli nawet, to liczba błędów, pomyłek i opuszczeń wypaczyła w wielu miejscach jego sens. Opuszczenia i omyłki są szczególnie istotne z punktu widzenia historii medycyny, ponieważ dotyczą m.in. nazw lekarstw podanych Batoremu czy opisu wyglądu narządów wewnętrznych w trakcie dokonywanej sekcji zwłok króla. Natomiast rkps AGAD, który najprawdopodobniej był podstawą wydania tekstu w „Przyjacielu Ludu", opublikowany został z pomyłkami, aczkolwiek nielicznymi, bez podania informacji o proweniencji źródła. Zestawienie ze sobą obu rękopisów pozwoli badaczom w pełniejszy niż dotąd sposób przeanalizować symptomy choroby Stefana Batorego, a może także rzuci nowe światło na przyczyny śmierci króla.

\section{Charakterystyka rękopisu}

Dokument Śmierci Stefana JMci... (Prawdziwa sprawa...) powstał w krótkim czasie po zgonie Stefana Batorego (12 XII 1586). Jego autorem najprawdopodobniej był Jakub Gosławski, jeden z lekarzy przebywających w otoczeniu monarchy. W jednym z pism polemicznych Mikołaj Bucella wymienił obecne przy sekcji zwłok króla osoby, w tym dwóch lekarzy - siebie i Gosławskiego ${ }^{16}$. O Gosławskim wiadomo niewiele. Przed pojawieniem się na dworze Stefana Batorego był lekarzem wojewody wileńskiego Mikołaja Radziwiłła ${ }^{17}$. W czasie pierwszego bezkrólewia po śmierci Zygmunta Augusta interesował się sytuacją polityczną w Rzeczypospolitej i prowadził na ten temat korespondencję z Janem Chodkiewiczem. Przekazywał z Warszawy informacje o pogłoskach szerzących się w Koronie, które dotyczyły separatystycznej elekcji na Litwie ${ }^{18}$. Oprócz panujących w Warszawie nastrojów informował Chodkiewicza także o ustaleniach dotyczących sposobu przeprowadzenia wolnej elekcji ${ }^{19}$. Na dworze

\footnotetext{
${ }_{16}$ M. Bucella, Refutatio scripti Simonis Simonii, s. 105.

17 A. Knot, Dwór lekarski Stefana Batorego, s. 184.

18 BKórn., sygn. 11617, J. Gosławski do J. Chodkiewicza, Warszawa, 21 I 1573 i 24 I 1573.

19 Tamże, J. Gosławski do J. Chodkiewicza, Warszawa, 26 I 1573.
} 
u króla Stefana Batorego sprawował nadzór nad kuchnią królewskąa ${ }^{20}$ W czasie panowania Zygmunta III Wazy pełnił funkcję lekarza nadwornego, wraz z królem udał się w 1593 r. w podróż do Szwecji ${ }^{21}$. Tadeusz Rejmanowski zaliczył Gosławskiego w poczet lekarzy włocławskich, uznając za prawdopodobne, że osiadł i praktykował we Włocławku po uzyskaniu spadku po swoim krewnym, mieszczaninie Janie Gosławskim (Jakub miał być świadkiem 31 XII 1603 przed sądem biskupim we Włocławku w sprawie tej schedy ${ }^{22}$. Niestety autor nie podał źródeł tych informacji, trzeba więc traktować je ostrożnie, podobnie jak to, że mieszkając w Warszawie, Gosławski opiekował się dziećmi zmarłego doktora medycyny Klemensa z Radziwia. Informacji takich nie podaje biogram Jana Klemensa Radziwina w PSB ${ }^{23}$.

Niestety oryginału dzieła Gosławskiego nie udało się odnaleźć. Współcześnie istnieją dwa odpisy dokumentu (choć nie można wykluczyć, że jest ich więcej). Rkps AGAD znajduje się w Dziale II Archiwum Radziwiłłów, który zawiera miscellanea - dokumenty historyczne rozmaitej proweniencji (korespondencję królewską i ważnych osobistości życia publicznego, rozporządzenia, instrukcje sejmikowe, mowy, traktaty, pieśni itp.). W księdze 12, liczącej 1135 stron, znajdują się dokumenty z lat 1606-1644. Jak wynika zatem z opisu księgi, dokument Śmierć Stefana Jmci... nie powinien się tam znaleźć, ponieważ powstał wcześniej. Miejsce jego umieszczenia w księdze jest dość przypadkowe tekst znajduje się nie na początku (wówczas można by doszukiwać się chronologicznego układu treści) ani nie na końcu (gdzie zazwyczaj pojawiają się dokumenty niedatowane lub takie, których czasu powstania kopista nie był w stanie określić), a mniej więcej w trzech czwartych objętości woluminu. Następnym znajdującym się w kolejności dokumentem jest odpis testamentu Stefana Batorego. Brak informacji zarówno o osobie, która umieściła dokument w księdze, jak i o kopiście (kopistach?), którzy przepisywali do niej pozostałe dokumenty.

Drugi będący podstawą niniejszego wydania dokument, rkps BCzart., znajduje się w zbiorze Teki Naruszewicza w Bibliotece Książąt Czartoryskich w Krakowie. Teka zawiera kopie dokumentów z lat 1584-1586 o różnym charakterze (listy, uniwersały, dekrety, protestacje, okolicznościowa literatura polityczna). Zbiór liczy 640 stron (plus VIII stron początkowych, gdzie umieszczono spis treści sporządzony w XIX w. przez Feliksa Bentkowskiego). Teka oprawiona jest w płótno wyklejone papierem marmurkowym. Na grzbiecie naklejono fragment starego grzbietu z tytułem Teka Naruszewicza oraz datami: 1584-1586. Prawdziwa sprawa... została umieszczona pod koniec tomu.

Odpis z rękopisu sporządził nieznany bliżej kopista Michał Kalinowski. Pismo kopisty jest staranne, jednakże popełnił on wiele błędów, wynikających najpewniej z pośpiechu oraz niewystarczającej znajomości łaciny. Poprawek w obrębie Teki dokonywała najpewniej jedna osoba, na co wskazuje charakter pisma. Pod jednym ze znajdujących się tam dokumentów widnieje informacja, że sprawdzenia $z$ oryginałem dokonał Adam Naruszewicz, jest więc prawdopodobne, że to właśnie on naniósł poprawki również w tekście Prawdziwej sprawy... ${ }^{24}$.

W dwóch miejscach na pierwszej stronie dokumentu (w prawym górnym rogu oraz pod tytułem dokumentu po prawej stronie) znajduje się informacja o jego proweniencji - Archiwum Stanisława Augusta Poniatowskiego. Dopisek pod tytułem dokonany został przez osobę nanoszącą poprawki na tekst. Niestety literatura poświęcona temu archiwum oraz losom samych Tek Naruszewicza nie przynosi odpowiedzi na pytanie, z którego konkretnie działu archiwum Poniatowskiego zaczerpnięto dokument oraz czy jego oryginał zachował się do naszych czasów ${ }^{25}$.

20 A. Knot, Dwór lekarski Stefana Batorego, s. 184.

${ }^{21}$ C. Lechicki, Mecenat Zygmunta III i życie umystowe na jego dworze, Warszawa 1932, s. 297; W. Leitsch, Das Leben am Hof König Sigismundus III. von Polen, t. 1, Kraków 2009, s. 306-307.

${ }^{22}$ T. Rejmanowski, Lekarze włocławscy w stużbie królów polskich, „Meritum”, 2007, nr 3, <www.oil.org.pl/xml/oil/oil67/ gazeta/numery/n2007/n200703/n20070312> [dostęp: 9.10.2017].

23 A. Sołtan, Radziwin Jan Klemens, w: PSB, t. 30, Wrocław 1987, s. 421-422.

${ }^{24}$ Naruszewicz niekiedy osobiście kolacjonował teksty i poświadczał ich właściwe skopiowanie, mimo że zadanie to teoretycznie należało do rejestrantów. W praktyce jednak finansowanie kancelarii było niewystarczające, a uzyskane środki pozwalały opłacić pracę głównie kopistów; S. Grzybowski, Teki Naruszewicza. „Acta regum et populi Poloni”, Wrocław 1960, s. 18-20.

25 Tamże, passim; P. Bańkowski, Archiwum Stanisław Augusta. Monografia archiwoznawcza, Warszawa 1958, passim. 
Rkps AGAD i rkps BCzart. są do siebie zbliżone, ale nie identyczne. Różnice, oprócz ortograficznych, interpunkcyjnych i szyku wyrazów oraz spraw drobnych, obejmują także istotne z punktu widzenia historii medycyny rozbieżności.

Przede wszystkim zauważyć należy, że niektóre wyrazy, pierwotnie w obu dokumentach tożsame, w rkps BCzart. zostały poprawione po kopiście. Dotyczy to zarówno oczywistych pomyłek (np. słowo „plech kąsanie” występujące w obu rękopisach w rkps BCzart. poprawiono na „pcheł kąsanie”), jak i poprawnych wyrazów i wyrażeń, które zamieniono (np. „ścierano” w rkps BCzart. konsekwentnie poprawiano na „nacierano”, a „mało sprawiła” na „mało pomogła”). Gdyby wziąć pod uwagę tylko tego typu różnice, można by sądzić, że oba odpisy dokonane zostały z tej samej podstawy źródłowej. Jednocześnie jednak inne przesłanki pozwalają domniemywać, że kopie powstały jako wynik pracy nad dwoma różnymi podstawami. Pierwszą istotną różnicą jest skala obrażeń, jakich doznał Batory w wyniku upadku w nocy z 7 na 8 grudnia. W rkps AGAD czytamy, że król „w twarz w jagodę się prawą ranił”, natomiast w rkps BCzart.: „w twarz, w jagodę prawą się ranił, i w czoło i w nos”. Duże rozbieżności pojawiają się w protokole sekcji zwłok króla, a dotyczą położenia i wyglądu organów wewnętrznych. Przykładowo: „płuca, jeno że były przymiękciejsze” (rkps AGAD) - „płuca, jedno że były przy sercu” (rkps BCzart.); „,nerki [...] górkowate” (rkps AGAD) - „,nerki [...] garkowate” (rkps BCzart.). Ponadto w rkps AGAD brak szczegółowych informacji na temat okresu życia i panowania Stefana Batorego. Warszawski rękopis nie zawiera także diagnozy, którą postawił jeden z królewskich lekarzy, występującej w rkps BCzart. Mowa o fragmencie, w którym zapytany przez autora o przyczynę śmierci monarchy Symoniusz odpowiedział ,asthma cum sincope, i accusabat aquam”. Jeśli fragment ten nie został w rkps AGAD po prostu przez pomyłkę ominięty, może to świadczyć, że sam tekst (lub jego podstawa źródłowa) jest starszy i pochodzi sprzed polemiki królewskich medyków ${ }^{26}$.

Do niniejszego wydania postanowiono dołączyć również tekst wydany przez E. Raczyńskiego w 1830 r. (z zaznaczeniem drobnych różnic w przedrukach z 1836, 1839 i 1849 r.). Pozwoli to badaczom porównać skalę różnic i opuszczeń między pierwszym wydaniem a rkps AGAD i rkps BCzart.

\section{Zasady wydania}

Teksty będące podstawą niniejszej edycji zostały zmodernizowane według zaleceń instrukcji Kazimierza Lepszego ${ }^{27}$. Dla lepszego porównania różnic między rkps AGAD a rkps BCzart. teksty umieszczono $\mathrm{w}$ tabeli. Podział na akapity został wprowadzony w obu tekstach na podstawie zaznaczenia podziału tekstu wprowadzonego drugą ręką w rkps BCzart. Wszelkie skrócenia występujące w tekstach rozwiązano (również te oznaczające dostojeństwo lub tytuł), w przypisie podając ich oryginalne brzmienie. Pisownię zmodernizowano również według zasad instrukcji K. Lepszego. Łączna i rozdzielna pisownia poszczególnych wyrazów oraz pisownia dużych liter została dostosowana do zasad obowiązujących współcześnie. Interpunkcję także zmodernizowano zgodnie z obecnymi regułami, starając się jednak, aby nie zmieniło to sensu pierwotnego przekazu. Cytaty zamieszczono w cudzysłowie. Nieliczne uzupełnienia wydawcy w tekstach rękopisów zapisano w nawiasach kwadratowych.

W przypadku rkps BCzart. edycja została przygotowana na podstawie tekstu kopisty, a poprawki drugiej ręki, pomimo że w wielu miejscach były poprawne i logiczne, oznaczono w przypisach. Dzięki temu przy porównaniu obu kopii łatwiej jest odnaleźć podobieństwa między nimi. Nie odnotowano jedynie tych zmian wprowadzonych przez drugą rękę, które poprawiały ewidentne błędy w pisowni wyrazów popełnione przez kopistę, są niezgodne z obecną pisownią i interpunkcją oraz typowych błędów o charakterze lapsus calami.

${ }^{26}$ Pierwszym pismem polemicznym, w którym występuje zwrot „syncope asthmatica” jest pismo Bucelli z 1587 r.; [M. Bucella], Epistola gen. d. Georgii Chiakor, k. B.

${ }^{27}$ K. Lepszy, Instrukcja wydawnicza dla źródel historycznych od XVI do połowy XIX wieku, Wrocław 1953. W przypadku gdy instrukcja nie omawiała niektórych kwestii, zastosowano zasady przyjęte w kompendium: J. Tandecki, K. Kopiński, Edytorstwo źródeł historycznych, Warszawa 2014. 
W przypisach zastosowano następujące skróty:

$\mathrm{O} \quad$ - jak w oryginale

W1 - Prawdziwa sprawa o chorobie i śmierci króla Stefana, w: Pamiętniki do historyi Stefana króla polskiego, wyd. E. Raczyński, Warszawa 1830, s. 143-149

W2 - „Wizerunki i Roztrząsania Naukowe”, poczet nowy, t. 9, Wilno 1836, s. 118-123

W3 - L. Gąsiorowski, Zbiór wiadomości do historyi sztuki lekarskiej w Polsce od czasów najdawniejszych aż do najnowszych, t. 1, Poznań 1839, s. 284-287

W4 - „Przyjaciel Ludu”, 1 VII 1843, R. 10, t. 1, s. 3-7

W5 - Panowanie Henryka Walezyusza i Stefana Batorego królów polskich z rękopisów Albertrandego podtug wydania Ż. Onacewicza. Z dołaczeniem pamiętników historyi Stefana Batorego dotyczacych, Kraków 1849, s. 442-444

\section{Edycja tekstów}

\author{
AGAD, Archiwum Radziwiłłów, dz. II, ks. 12 \\ Śmierć Stefana Jegomości króla polskiego w Grod- \\ nie 12 Decembra Anno Domini $1586^{28}$
}

Król Jegomość ${ }^{29}$ mając na prawej nodze poniżej dwa palca $^{30}$ od kolana speciem haeresi Palladis ${ }^{31}$, aż do kostki, w którym były ${ }^{32}$ ranki niegłębokie, ciekące. $\mathrm{Na}$ tejże nodze niżej kolana miał aperturę ${ }^{33}$ uczynioną; przychodziło to raz $^{34}$ na czas, kiedy $\mathrm{z}$ owych ranek $i$ apertury mało ciekło, zatym nie miewał apetytu $^{35}$, noc niespokojną, niespanie, bo [po] wszystkim ciele zdało mu się jakoby go pchły kąsały; miał na to remedium ${ }^{36}$, że go ścierano po ręku chustami ciepłymi po nogach, po żywocie, po grzbiecie i po wszystkim ciele, zatym ${ }^{37}$ to odchodziło.

Toż nań ${ }^{38}$ przyszło w niedzielę quae suit 7 Decembris $^{39}$ i nie wieczerzał, ścierali go tylko po ręku i po nogach, a miasto wieczerzy jadł zupę z chleba, z wina z cukrem dla spania; położywszy się na łożu nie spał, tęsknośćc ${ }^{40}$ i ono jakoby płech ${ }^{41}$ kąsanie

${ }^{28} \mathrm{O}$ - Śmierć Stephana JeMści króla polskiego w Grodnie 12 Xbra A.D. 1586; W4 - Śmierć Stefana JMci, króla polskiego, w Grodnie, 12 Decembr. 1586.

${ }^{29}$ O - JM; W4 - Jmość.

${ }^{30} \mathrm{~W} 4$ - na prawej nodze na dwa palce.

${ }^{31}$ W4 - specimen heresi Palladis.

32 W4 - bywały.

${ }_{33}$ Apertura - otwór, inaczej sztuczna rana, jątrznik.

${ }^{34} \mathrm{~W} 4$ - nam.

${ }^{35} \mathrm{O}$ - appetitu.

${ }^{36} \mathrm{~W} 4$ - remedia.

${ }^{37} \mathrm{~W} 4$ - zaczem.

${ }^{38} \mathrm{O}$ - nam.

${ }^{39} \mathrm{O}-$ Decemb.

${ }^{40} \mathrm{~W} 4$ - tęschność.

${ }^{41}$ W4 - pcheł.

\section{BCzart., Teki Naruszewicza, nr 91}

Prawdziwa sprawa o chorobie i śmierci nieboszczyka Stefana Batorego króla polskiego ${ }^{137}$

Król Jegomość ${ }^{138}$ mając na prawej nodze poniżej na dwa palce od kolana speciem serpallatis ${ }^{139}$ aż do kostki, w którym bywały ranki niegłębokie ciekące, na tejże nodze niżej kolana miał aperturę uczynioną. Przychodziło to nań [raz] na czas, kiedy z onych ranek i apertury mało ciekło, zatym ${ }^{140}$ nie miewał apetytu, noc niespokojną, niespanie, bo po wszystkim $^{141}$ ciele zdało mu się jakoby go pchły kąsały. Miał na to remedium, że go ścierano ${ }^{142}$ po ręku chustami ciepłemi, po nogach, po żywocie, po grzbiecie, i po wszystkim ${ }^{143}$ ciele, zaczym ${ }^{144}$ to odchodziło. Toż nań przyszło w niedzielę, quae suit 7 decembris, i nie wieczerzał, ścierali ${ }^{145}$ go tylko po ręku i po nogach, a miasto wieczerzy, jadł drobiankę z chlebem ${ }^{146}, \mathrm{z}$ wina, $\mathrm{z}$ cukru, dla spania: położywszy się na łożu nie spał, tęschność ${ }^{147}$ i ono jakoby płech $^{148}$ kąsanie, z niejakim ${ }^{149}$ czuciem gorącości

\footnotetext{
137 O - Pols, druga ręka: Polskiego.

${ }_{138} \mathrm{O}$ - Imć.

139 Druga ręka: speciem serpellatis.

140 Druga ręka: zatem.

${ }^{141}$ Druga ręka: wszystkiem.

142 Druga ręka: nacierano.

${ }_{143}$ Druga ręka: wszystkiem.

144 Druga ręka: zaczem.

145 Druga ręka: nacierali.

146 Druga ręka: chleba.

147 Druga ręka: tęskność.

148 Druga ręka: pcheł.

149 Druga ręka: niejakiem.
} 
z niejakim czuciem gorącości w głowie. Potym w nocy wstał na stolec i tam długi czas był na zimnie i na wietrze, idąc do stolca przez komórkę, która jest między miejscem stolca $a^{4}{ }^{42}$ wychodka, a między komnatką, gdzie leżał. W tej komorze, gdy nogami grzebł, usłyszał Węgrzyn, co przy nim sypiał. Otworzył do owej komórki i nalazł króla klęczącego $^{43} \mathrm{u}$ drzwi, u ławy. Spytał go: „co się dzieje Miłościwy Królu?” ${ }^{4}$. Król rzekł: „nie wiem, co się dzieje" ${ }^{45}$. Rzekt ${ }^{46}$ : „,czemu Wasza Królewska Mość ${ }^{47}$ upadł?”, król rzekł: „nie wiem, co się ze mną działo" ${ }^{\text {"48 }}$. Potym go za rękę podniós ${ }^{49}$ i obaczył, a ono od kolana wszytka noga krwawa z rany, która była nad czaszką nad dwa palce ${ }^{50}$, nie barzo głęboka, ale długa i szeroka; nie wiedział Król Jegomośćć jako się ranii ${ }^{52}$, ale podobieństwo, że o skrzynię, która była śród komórki, ale większe podobieństwo, iż o ławę, bo i w twarz $\mathrm{w}$ jagodę się prawą ranit ${ }^{53}$ i znać, iż gdy upadł z uderzenia o ławę, zatym twarzą na ścianę gołą, bo ta komórka nie była obita. Szedł potym do Łukasza (sic!) i posłał do doktora Symoniusza $^{54}$, bo Bucelli55 nie było w Grodnie.

${ }^{42} \mathrm{~W} 4$ - albo raczej.

$43 \mathrm{O}$ - klęczące.

${ }^{44} \mathrm{O}$ - MK; W4 - JM. Królu.

${ }^{45} \mathrm{~W} 4$ - ,nie wiem”.

46 W4 - Rzekł znowu.

${ }^{47} \mathrm{O}$ - WKM; W4 - WKM.

${ }^{48} \mathrm{~W} 4$ - stało.

${ }^{49}$ W4 - powiódł.

$50 \mathrm{O}$ - palca.

${ }^{51} \mathrm{O}$ - KJM; W4 - król Jmć.

52 W4 - zranił

${ }^{53}$ W4 - podobnieństwo było, że o skrzynią, która stała śród komórki, albo o ławę, bo i w twarz w jagodę się prawą ranił, i w czoło.

${ }^{54} \mathrm{O}$ - Symoniusa. Simone Simoni - lekarz włoski. Doktorat medycyny uzyskał w Padwie, następnie pracował w Genewie, Paryżu i Lipsku. Zaliczany w poczet lekarzy nadwornych cesarza Rudolfa II, w 1583 r. rozpoczął służbę lekarską na dworze Stefana Batorego. Tu skonfliktował się z innym lekarzem nadwornym władcy - Mikołajem Bucellą, którego później oskarżał o chęć otrucia Batorego. Po śmierci króla Simoni prowadził z Bucellą polemikę, próbując w wydawanych traktatach udowodnić winę adwersarza i słuszność swoich zaleceń co do królewskiego leczenia. Po śmierci Stefana Batorego przebywał na Morawach i w Pradze, zm. w 1602 r. w Polsce. Szerzej o tej postaci zob.: L. Szczucki, Simoni Simone, w: PSB, t. 37, Warszawa-Kraków 1997, s. 529-532; C. Madonia, Simone Simoni, w: Bibliotheca dissidentium, t. 9, Baden-Baden 1988, s. 25-110.

${ }_{55} \mathrm{O}$ - do Buccelle; W4 - Bucella. Mikołaj Buccella - lekarz włoski. Działalność lekarską prowadził w Padwie, Belluno, Wiedniu i na Morawach. Na dwór siedmiogrodzki trafił w głowie. Potym ${ }^{150}$ w nocy wstał na stolec, i tam długi czas był na zimnie i na wietrze. Idąc od stolca przez komórkę, która jest między miejscem stolca a między komnatą, gdzie leżał, w tej komorze ${ }^{151}$ gdy nogami grzebł, usłyszał węgrzyn ${ }^{152}$, co przy nim sypiał, otworzył [drzwi] do onej komórki, i nalazł króla u drzwi klęczącego u ławy. Spytał go, „,co ${ }^{153}$ się dzieje Miłościwy ${ }^{154}$ Królu”? Król rzekł: „nie wiem, co ${ }^{155}$ się dzieje”; rzekł156: ,a czemu Wasza Królewska Mość157 padł”? Król rzekł: „nie wiem, co się ze mną pomoże działo" 158 . Potym ${ }^{159}$ go za rękę podniósł, i obaczył, a owo od kolana wszytka noga krwawa $z$ rany, która była nad czaszką na dwa palcy ${ }^{160}$, nie bardzo głęboka, ale długa i szeroka. Nie wiedział król jako się ranił: podobieństwo, że o skrzynię, która była w zszód komory ${ }^{161}$, ale większe podobieństwo, że o ławę, bo i w twarz, w jagodę prawą się ranił, i w czoło i w nos. Znać, iż gdy upadł $\mathrm{z}$ uderzenia o ławę, za tym ${ }^{162}$ twarzą na ścianę gołą, bo ta komórka nie była obita. Szedł potym ${ }^{163}$ do łóżka, i posłał po doktora Symoniusza, bo Bukcelle ${ }^{164}$ nie było w Grodnie.

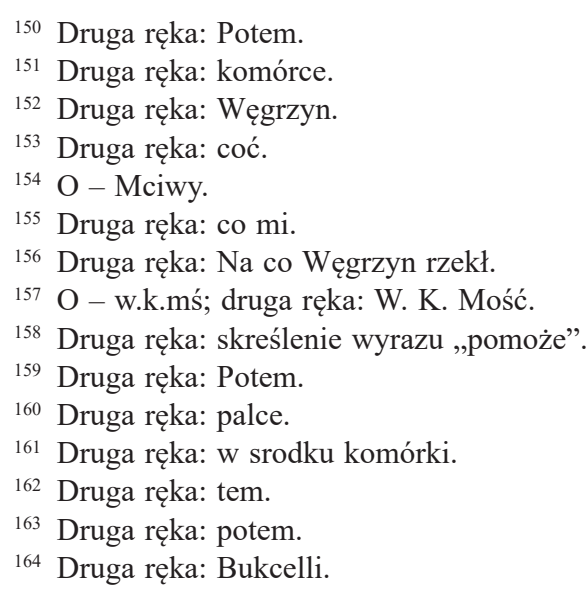


To się działo o godzinie jedenastej z niedzieli na poniedziałek 7 Decembra ad 8 Decembra ${ }^{56}$. W poniedziałek 8 dies $^{57}$ dał mu Symoniusz ${ }^{58}$ mannę, która go mało sprawiła; na obiedzie barzo mało jadł, wino pił, od tego ${ }^{59}$ czasu żaden na pokój nie chodził, tylko ci dwaj doktorowie ${ }^{60}$, bo Bucella we wtorek przyjechał, a dwaj Węgrzynowie Ferens ${ }^{61}$ a Lepszenin $^{62}$, i kazał aby o tym stłuczeniu żadnemu nie powiadali ${ }^{63}$. A iż $\mathrm{w}$ poniedziałek mało go manna sprawiła $^{64}$, we wtorek namówił go Ferens aby wziął konfek $t^{65} \mathrm{z}$ kwiatów brzoskwiniowych, których sam używał, i wziął. A iż była wnętrzna gorączka, którą ledwo pulsu czuć było, a z wierzchu ziębnął, nie dali mu samego ${ }^{66}$ wina, ale $\mathrm{z}$ wodą. Napiwszy się raz abo dwa na obiedzie ${ }^{67}$ onego $^{68}$ wina $\mathrm{z}$ wodą,

w latach 70. XVI w., po wyborze Batorego na króla Rzeczypospolitej przeniósł się wraz z władcą do Polski. Cieszył się zaufaniem monarchy, co przekładało się na łaski i nadania. Po śmierci Batorego został lekarzem m.in. Zygmunta III Wazy. Prowadził polemikę z Simonim, broniąc swoich racji w leczeniu Batorego, zm. w 1599 r. Szerzej o tej postaci zob.: K. Lepszy, Buccella Mikołaj, w: PSB, t. 3, Kraków 1937, s. 74-75; A. Knot, Dwór lekarski Stefana Batorego, s. 158-183.

${ }^{56} \mathrm{O}-7$ decem. ad 8 decem; W4 - 7go na 8go Dec.

${ }^{57} \mathrm{O}-$ die; W4 - Decemb.

${ }^{58} \mathrm{O}-$ Symonius.

${ }^{59} \mathrm{O}-$ te; W4 - do tego.

${ }^{60} \mathrm{O}$ - doctorowie.

${ }^{61}$ Ferens - prawdopodobnie Franciszek Wesselini (Ferenc Wesélenyi) - współpracownik Stefana Batorego, jeden z ulubieńców króla. W 1582 r. otrzymał godność barona siedmiogrodzkiego, a w 1590 r.. polski indygenat. Szerzej o tej postaci i dziejach rodziny Wesélenyi zob.: K.R. Prokop, Stanisława Wojeńskiego droga do biskupiej infuty. Perypetie kościelnej kariery syna rektora Akademii Krakowskiej, „Biuletyn Biblioteki Jagiellońskiej”, 67, 2017, s. 115-117; E. Budzińska, Franciszek Wesselini, dworzanin króla Stefana Batorego - nagrobek i ,portret”, w: Polska i Europa $w$ dobie nowożytnej. L'Europe moderne: noveau monde, nouvelle civilisation? Modern Europe - New World, New Civilisation? Prace naukowe dedykowane Profesorowi Juliuszowi A. Chrościckiemu, red. T. Bernatowicz, Warszawa 2009, s. 529-534.

${ }^{62}$ Lepszenin - określany także jako Kiepszen lub Kiepszea, jeden z Węgrów z otoczenia Stefana Batorego. Na jego ślad nie udało się trafić w innych źródłach czy literaturze przedmiotu.

${ }^{63}$ W4 - i zakazal, aby o tem sthuczeniu żadnemu nie powiadali.

${ }^{64}$ W4 - w poniedziałek 8. Decembr. dał mu Symoniusz mannę, która go mało sprawiła.

${ }^{65} \mathrm{O}$ - Confect.

${ }^{66} \mathrm{O}$ - same.

${ }^{67} \mathrm{~W} 4$ - po obiedzie.

${ }^{68} \mathrm{O}-$ one.
To się działo z niedzieli na poniedziałek. O godzinie $11 \mathrm{w}$ poniedziałek dał mu Szymoniusz ${ }^{165}$ mannę, która go mało sprawiła ${ }^{166}$. Na obiedzie zjadł ${ }^{167}$ bardzo mało, wino pił. Od tego czasu żaden napój ${ }^{168}$ nie chodził, tylko ci dwa doktorowie, bo Bukcella we wtorek przyjechał, a dwa Węrzynów, Ferens a Kiepszen. Zakazał aby o tym ${ }^{169}$ stłuczeniu żadnemu nie opowiadali. A iż w poniedziałek manna go mało sprawiła $^{170}$, we wtorek namówił go Ferens, aby wziął konfekt z kwiatów brzoskwiniowych, których sam używał, i wziął, a iż była wnętrzna gorączka, którą było ledwie w pulsiech czuć, a $\mathrm{z}$ wierzchu ziębnął, nie dali mu samego wina, ale $z$ wodą. Napiwszy się raz abo dwa na obiedzie onego ${ }^{171} \mathrm{z}$ wodą, wypił szklankę wódki cynamonowej mocnej, także i na wieczerzy. Siedział na łóżku i po wieczerzy, aż się doktorowie nawieczerzali z Ferensem. Potym rzekł król iż chce spać. Skoro się układł, rzekł: ,jużci mnie napadła pierwsza choroba". To było o godzinie 10 na półzegarzu w nocy. Za tym ${ }^{172}$ nogi spuścił, jakoby chciał wstać, a oczy wywrócił w zgórę, i zakręciwszy się zęby zgrzytając ${ }^{173}$, a oni ${ }^{174}$ tarli zaraz głowę, uszy ciągnęli, palce u nóg i ręce. Potym ${ }^{175}$ gdy ku sobie przyszedł, a otworzywszy oczy, rzekł: „dla Boga, co czynicie”? Rzekli „Wasza Królewska Mość ${ }^{176}$ źle się miał”. Odpowiedział: ,prawda jest”. Zatym $^{177}$ przyszła nań wielka duszność, że ledwie tchnął: jęli trzeć ręce, nogi, cisnąć palce, ale przecie duszność nie odchodziła. Potym ${ }^{178}$ przysadzili wielkie bańki na słabiznach, ścierając ${ }^{179}$ ciepło: poczęła ona duszność odchodzić, i tak onę noc miał bardzo ciężką i niespokojną.

\footnotetext{
165 Druga ręka: Symoniusz.

166 Druga ręka: która mu mało pomogła.

167 Druga ręka: jadł.

${ }^{168}$ Druga ręka: na pokój.

${ }^{169}$ Druga ręka: tem.

170 Druga ręka: manna mało mu pomogła.

${ }_{171}$ Druga ręka: onego wina.

172 Druga ręka: tem.

173 Druga ręka: zgrzytał.

174 Druga ręka: Oni.

175 Druga ręka: Potem.

176 O - W.K.M.; druga ręka: W.K.Mość.

177 Druga ręka: Za tem.

178 Druga ręka: Potem.

179 Druga ręka: nacierając.
} 
wypił szklankę wódki cynamonowej mocnej, także i na wieczerzy. Siedział na łóżku i po wieczerzy aż się doktorowie ${ }^{69}$ nawieczerzali i z Ferensem. Potym rzekł król, iż chce spać, skoro się układł, rzekł: ,już mnie ${ }^{70}$ napadła pierwsza choroba"; to było o dziesiątej $\mathrm{w}$ noc $^{71}$ na półzegarzu. Zatym nogi z łóżka spuścił, jakoby chciał wstać, a zatym oczy wywrócił w górę, zakręciwszy szyję ${ }^{72}$, zęby ${ }^{73}$ zgrzytając, a oni zaraz tarli głowę, uszy ciągnęli, palce u nóg i ręku ciągnąc. Potym, gdy do siebie przyszedł, otworzywszy oczy, rzekł: „dla Boga, co czynicie?”, rzekli: „Wasza Królewska Mośćc74 źleś się miał”. Odpowiedział ,prawda jest”; zatym przyszła wielka duszność, zaledwie ${ }^{75}$ tchną, jęli ${ }^{76}$ trzeć ręce, nogi, ciągnąc palce, ale przecie duszność nie odchodziła. Potym przysadzili wielkie bańki na słabiznach ścierając ciepło, poczęła owa duszność odchodzić, i tak onę noc miał barzo ciężką i niespokojną.

Nazajutrz we środę aby co ściągnęli z głowy ${ }^{77}$ pigułki 3 z Cohiar $i$ Extracti Hellebori gr. $\mathrm{V}^{78}$, które wypił, z wódką rozczynione lili convalii ${ }^{79}$, bo ich samych nie chciał wziąć. Na obiedzie barzo mało jadł, uskarżał [się] na wody, kazał przy sobie nalać wina szklenicę ${ }^{80}$, bo powiedział ${ }^{81}$, iż się źle miał od wody ${ }^{82}$. A gdy nalali wina dwie części, nie dał wody lać, mówiąc: „będę samo wino pił,

${ }^{69} \mathrm{O}$ - doctorowie.

${ }^{70} \mathrm{~W} 4$ - ci mię.

71 W4 - w nocy.

${ }^{72}$ W4 - zakręciwszy się.

${ }^{73} \mathrm{~W} 4$ - zębami.

${ }^{74} \mathrm{O}$ - WKM; W4 - W.K. Mość.

75 W4 - że ledwie.

${ }^{76}$ W4 - jęli znowu.

77 W4 - aby chorobę ściągnąc z głowy dali mu.

78 O - Helebori; W4 - 3 Cochiar. et extracti elebori. Cohiar to najpewniej Cochia, określenie dawnych aptecznych pigułek sporządzanych na dwa sposoby, zob. B. Parr, The London Medical Dictionary: Including under Distinct Heads Every Branch of Medicine Viz. Anatomy, Physiology, and Pathology, the Practice of Physic and Surgery, Therapeutics and Materia Medica; with whatever Relates to Medicine in Natural Philosophy, Chemistry, and Natural History, London 1809, t. 1, s. 453-454. Extract Hellebori to prawdopodobnie ekstrakt z ciemiernika, gdzie gr. V oznacza minimalne dawkowanie; tamże, t. 2, s. 447.

${ }^{79} \mathrm{O}$ - były convalii; W4 - lekką Convalii. Najpewniej chodzi o Lilium Convalium - odmianę lilii, z której sporządzano lekarstwo używane m.in. w napadach astmy; tamże, t. 2, s. 85.

${ }^{80} \mathrm{O}$ - sklenicę; W4 - szklenicę nalać wina.

${ }^{81} \mathrm{~W} 4$ - powiadał.

${ }^{82}$ W4 - Przetoż mu pozwolili wina dwie części, a trzecią wody.
Nazajutrz we śrzodę ${ }^{180}$ aby co ściągnęli z głowy, dali mu pigułki zychochiar et extracti hellebori ${ }^{181}$, które wypił z wódką rozczynione lili konwalii, bo ich tak samych nie chciał wziąć. Na obiedzie bardzo mało jadł, uskarżał się na wodę, iż się ${ }^{182}$ bardzo źle miał: pozwolili mu wina dwie części, a trzecią wody. Kazał przy sobie nalać szklenicę ${ }^{183}$ wina, a gdy nalali ${ }^{184}$ dwie części, nie kazał wody lać, mówiąc: „będę samo wino pił, będzieli trzeba, potem samą wodę”, i wypił, także i drugi raz, i rzekł: „lepiej”, także też i na wieczerzy, a bardzo mało jadł, a usta płukał wodą, bo miał pragnienie, a gdy się położył o siódmej godzinie na półzegarzu, znowu przyszła nań choroba, czynił jako i pierwej. Gdy ku sobie przyszedł, pytali go jeśli co czuje przed chorobą: powiadał, że mu coś wstępuje po lewej stronie w głowę.

\footnotetext{
Druga ręka: środę.

${ }^{81}$ Druga ręka: cochiarum et extracti hellebori.

182 Druga ręka: się od niej.

183 Druga ręka: szklanicę.

184 Druga ręka: naleli.
} 
będzieli trzeba, potem będę samą wodę pił"; i pił ${ }^{83}$ także i drugi raz i rzekł: „lepiej tak”, także też i na wieczerzy, a bardzo mało jadł, a usta płukał wodą, bo miał pragnienie. A gdy się już położył o siódmej godzinie $^{84}$ na półzegarzu znowu przyszła choroba, czynili jako ${ }^{85}$ i pierwej, gdy ku sobie przyszedł, także pytał: „co mi czynicie?”. A kiedy go pytali jeśli czuje co przed chorobą, powiedział: „iż mi coś wstępuje po lewej stronie w głowę".

W czwartek ${ }^{86}$ dali mu Castorej Scrup 3 aut 2 i Aquam $H_{i s o p i} i^{87}$, a przed obiadem stawiali ${ }^{88}$ bańki rzezane: dwie na prawej stronie pod łopatką i niżej, jedną na lewej stronie pod łopatką ${ }^{89}$, bo drugą trudno było iż leżał, a dwie małe na nodze prawej u kostki. A iż już widzieli, iż jest Species Caduci, abo raczej kaduk, nie chcieli mu dać wina, ale wodę zmieszaną, co najlepiej z chlebem i potym przeczynioną ${ }^{90}$. Nie chciał jej, ale sam wziąwszy chleb przekroił na dwie ${ }^{91}$, i włożył w wodę i mokło ${ }^{92}$. Potym się napił troszkę dwakroć, a bardzo mało jadł, jeno jaje świeże; zmieszali mu potym wodę $\mathrm{z}$ konfektem ${ }^{93}$ różanym i przecedzili, którą też pijał we zdrowiu ${ }^{94}$ niekiedy, i wypił jej razem z kwartę, bo bardzo pragnął. Potym po małym czasie spał spokojnie więcej niż ze dwie godziny ${ }^{95}$, mówił rzeźwie jako zdrowy. Na wieczerzy nie chciał jeść rozumiejąc, iż wieczerza wadziła. Bawili doktorowie ${ }^{96}$ aby godzina minęła, kiedy choroba nań przychodziła, ale skoro przyszła

${ }^{83}$ W4 - wypił.

${ }^{84} \mathrm{O}$ - siódmej godziny; W4 - siódmej godziny.

${ }^{85} \mathrm{~W} 4$ - jak.

86 W4 - we wtorek.

${ }^{87}$ W4 - Casterei scrup. 3 aut. 2. in aqua Hysopi. Prawdopodobnie zastosowano Castoreum, czyli tzw. strój bobrowy - wydzielinę z gruczołów skórnych bobra, stosowaną w czasach nowożytnych w wielu dolegliwościach. Castorerum podawano m.in. w przypadłościach dotykających głowy, jak ociężałość, zawroty, a także przeciw apopleksji czy paraliżowi; B. Parr, The London Medical Dictionary, t. 1, s. 363; J. Szostak, Vademecum lecznictwa domowego z roku 1563, Brzezia Łąka 2016, s. 310, 316. Aqua Hyscopi - połączenie wody z hyzopem, stosowane m.in. w chorobach płuc; A. Duncan, The Edinburgh New Dispensatory, Edynburg 1789, s. 468.

${ }^{88}$ W4 - stawili.

${ }^{89}$ W4 - dwie na prawej stronie pod łopatką, a niżej jednę na lewej stronie.

${ }_{90}$ W4 - octem przeczynioną.

${ }_{91}$ W4 - na czworo.

${ }_{92} \mathrm{~W} 4$ - i tak mokło.

${ }_{93} \mathrm{O}$ - confectem.

${ }^{94} \mathrm{~W} 4$ - we zdrowiu lecie.

${ }^{95} \mathrm{O}$ - godzinie.

${ }^{96} \mathrm{O}$ - doctorowie.
We czwartek dali mu - kasto ry in aqua hyscopi ${ }^{185}$, a przed obiadem stawiali bańki rzezane, dwie na prawej stronie pod łopatką, i niżej jedną po lewej stronie pod łopatką ${ }^{186}$, bo trudno było, iż leżał, drugą postawić, a dwie małe na nodze prawej u kostki. A iż już widzieli, że jest species caduci, albo raczej kaduk, nie chcieli mu dać wina, ale wodę zmieszaną co najlepiej chlebem ${ }^{187}$ (i potym przeczyniono). Nie chciał jej, ale sam wziąwszy chleb, przekroił na czworo, włożył w wodę, i tak mokło, potym ${ }^{188}$ napił się troszkę dwakroć, a bardzo mało jadł, jedno jaje świeże. Zmieszali mu potym ${ }^{189}$ wodę z konfektem różanym i przecedzili, którą też pijał niekiedy w zdrowiu w lecie, i wypił jej razem z kwartę, bo pragnął bardzo. Potym ${ }^{190}$ po małym czasie spał spokojnie więcej niż $2^{191}$ godziny, mówił rzeźwie jako zdrowy. Na wieczerzy nie chciał jeść, rozumiejąc, że mu wieczerza wadziła. Bawili go doktorowie, aby minęła godzina, kiedy choroba nań przychodziła, ale skoro przyszła 11. godzina na półzegarzu w nocy choroba przyszła, po której trudne oddychanie przez całą noc. Tejże nocy o 5. na półzegarzu przededniem, dali mu takież pigułki, uczyniwszy $\mathrm{z}$ nich bolum to jest konfekt.

\footnotetext{
${ }^{185}$ Druga ręka: kasto reum in aqua hyssopi.

${ }^{186} \mathrm{O}$ - pod łopatką pod łopatką, powtórzenie skreślone przez drugą rękę.

187 Druga ręka: z chlebem.

${ }^{188}$ Druga ręka: potem.

189 Druga ręka: potem.

${ }^{190}$ Druga ręka: Potem.

191 Druga ręka: dwie.
} 
jedenasta na półzegarzu w nocy, choroba przyszła, po której trudne oddychanie przez całą ${ }^{97}$ noc. Tejże nocy na półzegarzu o piątej przededniem dali takież pigułki uczyniwszy z nich bolum ${ }^{98}$, to jest konfekt. Na obiedzie barzo mało jadł, a pozwolili mu wina $\mathrm{z}$ troszką wody ${ }^{99}$. Po obiedzie był smętny, gorzej ${ }^{100}$ się miał, wszkaże nie nazbyt mdło ${ }^{101}$, sam wstał po czwartej na półzegarzu po południu. Przyszła potym choroba, od której go już wzbudzić nie mogli, bo zarazem ze ${ }^{102}$ śmiercią. Pytałem Bucellę ${ }^{103}$, jeśli kaduk miewał przedtym. [Powiedział], iż jeszcze w siedmiogrodzkiej ziemi przyszła nań była ${ }^{104}$ affectio więcej niż przez tydzień, co żadnym sposobem nie mógł mówić co chciał, kiedy chciał rzec Piotr, tedy rzekł Jan ect ${ }^{105}$; chociaż znał i pytał i pisał co jedno chciał i posły na ten czas cesarskie (którzy na ten czas u niego ${ }^{106}$ byli) przez pisanie odprawowat ${ }^{107} \mathrm{i}$ tu w Polszcze ${ }^{108}$ już temu pięć lat przyszło mu było w szyję przez kilka dni i z dusznością, także też potem już temu dwie lecie.

W niedzielę przyszłą, iż się był barzo nadął, przy bytności i Bucelli ${ }^{109}$ i mojej balwierze ${ }^{110}$ wyjmowali wnętrzności jego ${ }^{111}$ i Bucella ${ }^{112}$ im pomagał; wszystkie viscera zdrowiućkie ${ }^{113}$ : wątroba, także żołądek, śledziona, płuca jeno że były przymiękciejsze, serce zdrowe, nerki także, tylko lewa nadciekła bo się był potłukł barzo, nerki nadzwyczaj na kształt wołowych były, to jest górkowate, a niegładkie, a w człowieku ${ }^{114}$ są właśnie jako w skopie. Czego $^{115}$ ja ani Bucella ${ }^{116}$ nie widziałem w żadnym

97 W4 - wszystkę.

98 W4 - bulion.

${ }_{99} \mathrm{~W} 4$ - wina $\mathrm{z}$ troszką potem wody.

$100 \mathrm{O}$ - gorzy.

101 W4 - mdły.

102 W4 - zaraz z.

${ }^{103} \mathrm{O}$ - Bucelę.

104 W4 - była nań.

${ }^{105}$ W4 - brak łacińskiego zwrotu.

$106 \mathrm{O}$ - nie.

107 W4 - posły cesarskie, którzy natenczas u niego byli.

108 W4 - Polsce.

109 O - Bucele.

${ }^{110} \mathrm{O}$ - barwirze; W4 - barwierze.

${ }^{111} \mathrm{O}-$ je; W4 - z niego.

$112 \mathrm{O}$ - Bucela.

${ }^{113}$ W4 - zdrowiuteńkie.

$114 \mathrm{O}-\mathrm{w}$ człowiecze.

$115 \mathrm{O}-$ Cze.

${ }^{116} \mathrm{O}$ - Bucela; W4 - czego ani Bucella ani ja.
Na obiedzie bardzo mało jadł, a pozwolili mu trochę wina $z$ wodą. Po obiedzie był smutny, i gorzej się miał, wszakże nie nazbyt mdły sam wstawał (ustawał?). Skoro po czwartej na półzegarzu po południu, przyszła choroba, od której go już wzbudzić nie mogli, bo zarazem z śmiercią. Pytałem Bucellego ${ }^{192}$, jeśli kaduk miewał przedtym ${ }^{193}$. Iż ${ }^{194}$ jeszcze w siedmiogrodzkiej ziemi przyszła była nań affekcyja więcej ${ }^{195}$ niż przez tydzień, co ${ }^{196}$ żadnym obyczajem nie mógł mówić co chciał, kiedy chciał rzec Piotr, tedy rzekł Jan, chociaż znał i pamiętał, a pisał co jedno chciał. Posły cesarskie, którzy u niego na ten czas byli, przez pisanie odprawował, i tu w Polszcze, już temu $5^{197}$ przeszło lat, przyszło mu też ${ }^{198}$ było w szyję przez kilka dni i z dusznością, także też potym ${ }^{199}$, już temu dwie lecie.

$\mathrm{W}$ niedzielę przeszłą ${ }^{200}$, quae suit $14, \mathrm{iz}^{201}$ się był bardzo nadął, przy bytności Bucelli202 i mojej balwierze wyjmowali wnętrzności z niego, i Bucella ${ }^{203} \mathrm{im}$ pomagał. Wszystkie viscera zdrowiutkie, wątroba, także żołądek, śledziona, płucno ${ }^{204}$, jedno że były przy sercu, zdrowe, nerki także, tylko lewa naciekła, bo się był bardzo potłukł, nerki nadzwyczaj jako wołowe były, to jest garkowate a niegładkie, a w człowieku nerki są jako w skopie, czego ani Bukcella, ani ja nie widzieliśmy w żadnym ciele. Szukał Bukcella in omnibus visceribus: nie znalazło się nic tylko, jako to $\mathrm{z}$ ową ${ }^{205} \mathrm{w}$ onej macharzynce, kędy żółć bywa na wątrobie ${ }^{206} \mathrm{w}$ tej dziurze, kędy wychodzi żółć, kamień tak wielki jako muszkatołowa gałka, że do onej macharzynki nic nie

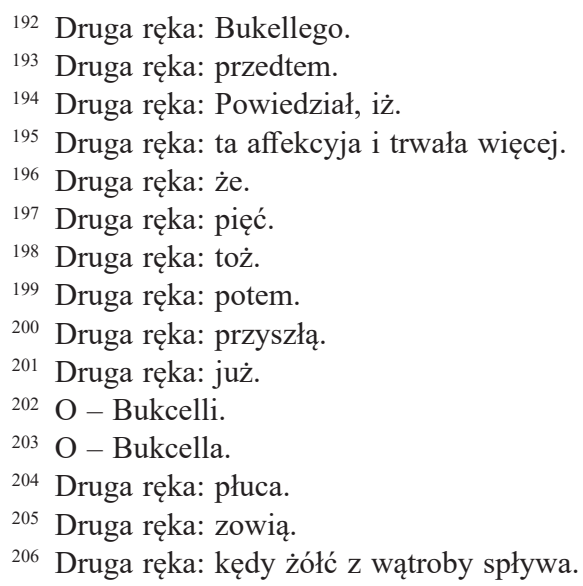


ciele. Szukał Bucella ${ }^{117}$ in omnibus visceribus, nie znalazło $^{118}$ się nic, tylko jako zowią w żełce prawej macharzynce ${ }^{119}$, kędy żółć bywa, na wątrobie w tej dziurce, kędy wchodzi żółć, kamień tak wielki jako muszkatołowa $^{120}$ gałka i na taki kształt, do którego ${ }^{121}$ macharzynka przywrzała, że do onej macharzynki nic nie wchodziło. Żółci w macharzynce nie było ${ }^{122}$, tylko woda szczera ${ }^{123}$. A drugi kamyk, wszakże to nie causa mortis, bo i w koniach ${ }^{124}$ żółci nie masz, bo się to rozchodzi po wszytkim ciele, i w tym Panu tak $^{125}$ to przychodziło, iż na czas bywały nań ${ }^{126}$ noce niespokojne i jakoby pchły kąsały.

Król Jegomość ${ }^{127}$ rozniemógł się 7 Decembra ${ }^{128}$ $\mathrm{z}$ niedzieli na poniedziałek, a umarł 12 Decembra $^{129}$.

Doktor Symoniusz ${ }^{130}$, gdym go pytał o śmierć Jego Królewskiej Mości ${ }^{131}$ pilnie co by było causa mortis albo coby acceleraret mortem ${ }^{132}$. Powiedział: „by był wino pił, mógłby jeszcze dzień abo trzy żyw być i Panu Bogu się sprawić i rzeczy rozprawić etc. ${ }^{133}$ ut fit Adam na Ewę, Ewa na węża. A przed się $^{134}$ grzech został, a najlepiej jednego ${ }^{135}$ słuchać, albo zgodnych a niewarchownych ${ }^{136}$.

$117 \mathrm{O}$ - Bucela.

${ }_{118}$ W4 - nie nalazło.

119 W4 - w żółci, w owej macharzynce. Macharzyna to synonim pęcherza moczowego.

${ }_{120} \mathrm{O}$ - muszkatowa; W4 - muszkatowa.

$121 \mathrm{O}$ - które.

${ }^{122}$ W4 - bynajmniej nie było.

${ }^{123} \mathrm{O}$ - szczyra.

${ }^{124}$ W4 - i w gołębiach i w koniach.

${ }^{125}$ W4 - stąd.

126 W4 - nań bywały.

$127 \mathrm{O}-\mathrm{Jm} ; \mathrm{W} 4-\mathrm{JM}$.

${ }_{128}$ O - Xbra; W4 - 7. Decembris.

${ }^{129} \mathrm{O}$ - Xbra; W4 - 12. Decembris.

${ }^{130} \mathrm{O}$ - Simonius; W4 - Simoniusz.

131 O - JKM; W4 - J.K.M.

132 W4 - acceleraret mortus.

133 W4 - brak łacińskiego zwrotu.

${ }^{134} \mathrm{~W} 4$ - a przecie.

${ }^{135} \mathrm{O}$ - jedne; W4 - albo jednego.

136 W4 - Dodatkowy akapit: „Testamentum Stephani Regis Poloniae, in Agone Mortis. Abbreviati sunt dies mei, sensus et manus officium suum exequi non possunt. Multa verba pronuntiare non valet Regnum paccatum et integrum Reipublicae relinquo. Huic et nepotes meos commendo". wchodziło żółci, jakoż i w macharzynce jej bynajmniej nie było, tylko woda szczera, a drugi kamyk. Wszakże to nie jest causa mortis, bo i w gołębiach i w koniach żółci nie masz, ale się rozchodzi po wszystkim $^{207}$ ciele, i w tym Panie stąd przychodziło, iż na czas bywały nocy niespokojne nań ${ }^{208}$, i to jako pchły kąsały.

Król Jegomośćc0 ${ }^{20}$ Stefan urodził się roku $1533^{210}$. Wjachał do Krakowa na Królestwo 1576, w poniedziałek po Wielkiejnocy. Panował lat 10, miesięcy 7, dni 12. Rozniemógł się w Grodnie 7 Decembris z niedzieli na poniedziałek, umarł 12 Decembris, roku 1586. Żył lat 50, miesięcy trzy ${ }^{211}$.

Doktor Symonius, gdym go pytał o śmierci króla Jegomości ${ }^{212}$, coby była za causa, powiadał, iż asina ${ }^{213}$ cum sincope, i accusabat aquam, którą król Jegomość ${ }^{214}$ pił, nie tak żeby była causa mortis, ale żeby ${ }^{215}$ miała accellerare ${ }^{216}$ mortem, i powiadał, „by był wino pił, mógłby był jeszcze dzień albo dwa bydź żyw, i $\mathrm{P}^{217}$ Bogu się sprawić, i rzeczy posprawiać": ita ut fit, Adam na Ewę, Ewa na węża, a przecie grzech został, a ono lepiej albo jednego słuchać, albo zgodnych a nie warchowliwych.

\footnotetext{
207 Druga ręka: wszystkiem.

${ }^{208}$ Druga ręka: bywały nań nocy niespokojne.

${ }^{209}$ O - Imć.

${ }^{210}$ Druga ręka: 27 septembris roku 1533 (z prawej strony skreślenie: 27 września).

211 Druga ręka: żył lat 53, miesięcy dwa, dni piętnaście.

${ }^{212} \mathrm{O}$ - Imci.

213 Druga ręka: asthma.

${ }^{214}$ O - Imć

215 Druga ręka: że.

216 Druga ręka: accelerare.

${ }^{217}$ Druga ręka: Panu.
} 
Tekst z wydania E. Raczyńskiego: (W1)

\section{Prawdziwa sprawa o chorobie i śmierci nieboszczyka Stefana Batorego Króla Polskiego}

Król jegomość miał na prawej nodze o dwa palce pod kolanem, aż do kostki, rodzaj wyrzutu, w którym bywały ranki niegłębokie ciekące. Na teyże nodze niżej kolana miał aperturę; a kiedy z niej mało ciekło, nie miewał apetytu, nocy były niespokojne i bezsenne.

Przyszła na niego choroba w niedzielę dnia 7. decembra ${ }^{218}$ i zdało mu się jakoby go pchły kąsały. Miał na to lekarstwo, że go ścierano chustami ciepłemi po wszystkiem ciele i tego też ${ }^{219}$ dnia ścierano go. Położywszy się na łoże, nie spał; czuł tęskność i owe ${ }^{220}$ jakby pcheł kąsanie, z niejakim czuciem gorącości w głowie. Potem w nocy wstał na prywatne miejsce i tam długi czas był na zimnie i wietrze. Idąc stamtąd przez komórkę, która jest przed komnatą, gdzie leżał, hałas się zrobił; usłyszał to Węgrzyn, co przy nim sypiał; otworzył do onej komórki i nalazł króla klęczącego we drzwiach u ławy; zapytał go: co się dzieje miłościwy królu? Król rzekł: nie wiem, co się dzieje; na to Węgrzyn: a czemu W. K. Mość padł. Król rzekł: nie wiem co się ze mną działo. A w tem zobaczył, że sobie zranił nogę, a prócz tego zakrwawił jagodę prawą, nos i czoło, z uderzenia o ławę ${ }^{221}$. Szedł potem do łóżka i posłał po doktora Symoniusza, bo Buccele ${ }^{222}$ dopiero we wtorek przyjechał.

W poniedziałek dał mu Symoniusz mannę, która go mało sprawiła. Na obiedzie jadł bardzo mało, pił wino: od tego czasu nikt do niego nie chodził, tylko doktorowie i dwa ${ }^{223}$ Węgrzy Terens i Kiepszea, a król zakazał, aby o tem stłuczeniu jego nic nie mówili; a iż w poniedziałek manna mało go sprawiła, we wtorek namówił go Terens, aby wziął konfekt z kwiatów brzoskwiniowych, których sam używał i wziął; a iż była wnętrzna gorączka, nie dali mu samego wina, ale z wodą. Napiwszy się raz albo dwa na obiedzie, wypił szklankę wódki cynamonowej mocnej; toż i na wieczór zrobił: potem rzekł król, iż chce spać. Skoro się układł, rzekł: jużci mnie napadła pierwsza choroba; to było o godzinie dziesiątej na pół zegarzu w nocy, zatem nogi spuścił ${ }^{224}$, jakoby chciał wstać; aż tu oczy wywrócił w górę, a zakręciwszy się, zgrzytał zębami, a oni tarli zaraz głowę, uszy ciągnęli ${ }^{25}$ i palce u nóg i ręce. Potem gdy ku sobie przyszedł, otworzywszy oczy, rzekł: dla Boga, co czynicie? Rzekli: W. K. Mość się źle miał ${ }^{226}$. Odpowiedział: prawda jest. Zatem przyszła nań wielka duszność, że ledwie tchnął; przysadzili więc wielkie bańki na słabiznach, a duszność poczęła odchodzić; i tak onę noc miał bardzo ciężką i niespokojną.

Nazajutrz we środę, aby ściągali krew do głowy ${ }^{227}$, dali mu pigułki Zielochanem et Extracti Elebori, które wypił. Na obiedzie bardzo mało jadł; uskarżał się na wodę; pozwolili mu więc doktorowie wina dwie części, a trzecią wody. Kazał przy sobie nalać szklanicęę28 wina; a gdy nalali dwie części, nie kazał wody lać, mówiąc: będę samo wino pił; i wypił toż i na wieczerzy, ale bardzo mało jadł, a usta płukał wodą, bo miał pragnienie. A gdy położył się o siódmej godzinie na półzegarzu, znowu przyszła choroba; czynił jako i pierwej; a gdy ku sobie przyszedł, powiadał, iż mu coś wstępuje po lewej stronie w głowę.

We czwartek dali mu Castorii et in aqua hysopi ${ }^{229}$, a przed obiadem stawiali bańki, dwie na prawej stronie pod łopatką, a niżej jedną po lewej stronie pod łopatką, a dwie małe na nodze nad kostką.

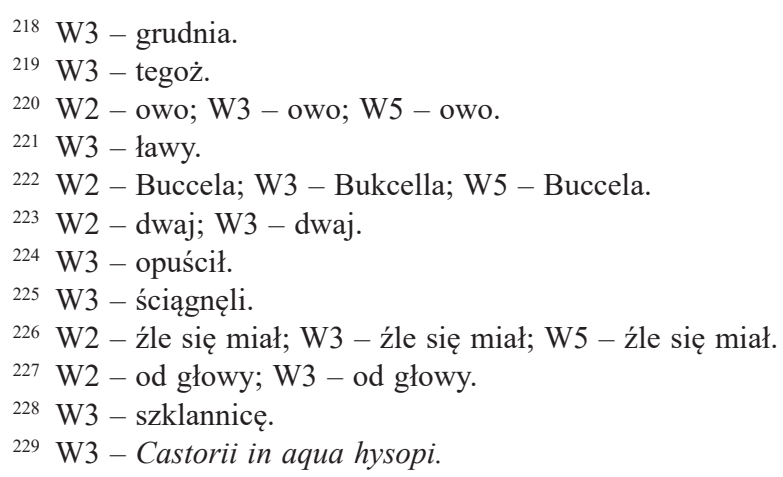


A iż widzieli, iż jest Species Caduci, albo raczej Kaduk, nie chcieli mu dać wina, ale wodęzmieszaną z chlebem. Sam więc król wziął chleb, przekroił na czworo, włożył w wodę i tak moczył. Potem napił się troszkę dwakroć, a bardzo mało jadł, jedno dwa jaja. Zmieszali mu potem wodę z konfektem mannym i przecedzili, którą też pijał niekiedy we zdrowiu w lecie, wypił jej razem z kwartę, bo miał wielkie pragnienie; potem po małym czasie spał spokojnie więcej niż dwie godziny, mówił rzeźwie ${ }^{230}$ jako zdrowy. Na wieczerzy ${ }^{231}$ nie chciał jeść, rozumiejąc iż mu wieczerza szkodziła. Bawili go doktorowie, aż minęła godzina, o której choroba nań przychodziła; ale skoro przyszła 11sta godzina na półzegarzu w nocy, choroba przyszła, po której trudne oddychanie przez całą noc. Tejże nocy o piątej na półzegarzu przededniem, dali mu takież pigułki, uczyniwszy z nich bolum, to jest konfekt.

Na obiedzie bardzo mało jadł, a pozwolili mu trochę wina $\mathrm{z}$ wodą. Po obiedzie był smętny ${ }^{232}$ i gorzej się miał, wszkaże nie nazbyt słaby sam wstawał, ale po czwartej godzinie po południu przyszła choroba, od której go już wzbudzić nie mogli, bo razem z śmiercią się skończyła. Pytałem się Buccela, jeżli król dawniej miewał kaduk; a powiedział, iż jeszcze w siemiogrodzkiej ziemi przyszła nań affectia ${ }^{233}$ więcej niż przez tydzień, co żadnym sposobem nie mógł mówić to co chciał, ale pamiętał i pisał dobrze. Posły cesarskie, którzy na ten czas u niego byli, pismem odprawował; i tu w Polszcze ${ }^{234}$ już temu pięć lat przeszło miał podobną chorobę przez kilka dni z ciężką dusznością.

Przy bytności Buccela balwierze wnętrzności wyjmowali z niego. Buccela im pomagał. Wszystkie viscera zdrowiuchne, wątroba także, żołądek, śledziono, płucno jedno przy sercu zdrowe, tylko lewe naciekło, bo się był bardzo potłukł. Nerki nadzwydzajne, jako wołowe; co dziwna, bo w człowieku nerki są jak w skopie. Czego ani Buccella, ani ja nie widzieliśmy w żadnem ciele. Szukał Bucccela in omnibus visceribus i nic nie znalazł, tylko w owej pęcherzynie, kędy żółć bywa w tej dziurze, kędy wychodzi, kamień tak wielki, jako muszkatowa gałka, że do onej pęcherzynki nic nie wchodziło żółci i nic jej też nie było, tylko woda szczera, i drugi kamyk; wszakże to nie jest causa mortis, bo i w gołębiach i koniach żółci nie masz, ale się rozchodzi po wszystkiem ciele.

Król jmćc ${ }^{235}$ Stefan rodził się ${ }^{236}$ w roku MDXXXIII i wjechał do Krakowa na królestwo MDLXXVI, panował lat 10, miesięcy 1, dni 12. Rozchorował się w Grodnie dnia 7. decembris, umarł dnia 12. decembris roku MDLXXVI ${ }^{237}$ (sic!). Żył lat 53, miesięcy 3, dni $16^{238}$.

Doktor Symoniusz ${ }^{239}$, gdym go pytał o śmieri króla jegomości coby była za przyczyna, powiada240, iż Asyna cum Syncope i accusabat aquam, którą K. J. M. pił, nie tak żeby była causa mortis, ale żeby miała accelerare mortem, i powiedział, by był wino pił, mógłby był jeszcze dzień albo ${ }^{241}$ dwa żyw być i Panu Bogu się sprawić, i rzeczy rozprawić. Ale tak się dzieje, Adam na Ewę, Ewa na węża spędza, a grzech zostaje.

\footnotetext{
${ }^{230} \mathrm{~W} 3$ - rzeźwio.

${ }^{231}$ W3 - wieczerzą.

${ }^{232}$ W2 - smutny; W3 - smutny.

233 W5 - affekcya.

${ }^{234}$ W5 - Polsce.

${ }^{235}$ W2 - Jegomość.

${ }^{236} \mathrm{~W} 2$ - urodził się.

${ }^{237}$ W2 - MDLXXXVI; W5 - MDLXXXVI.

${ }^{238}$ W3 - brak tego akapitu.

${ }^{239}$ W3 - Simoniusz.

${ }^{240}$ W2 - powiedział; W3 - powiedział.

${ }^{241} \mathrm{~W} 3$ - lub.
} 


\title{
The Death of His Majesty Stephen King of Poland at Grodno on 12 December Anno Domini 1586 (The Real Truth about the Illness and Death of Late King Stephen Bathory of Poland) - a source to Stephen Bathory's biography and history of medicine
}

\begin{abstract}
Summary: The sudden and unexpected death of Stephen Bathory, king of the Polish-Lithuanian Commonwealth, on 12 December 1586 provoked many hypotheses. Since the king was generally regarded as a healthy man in his prime, historians and physicians have for centuries tried to solve the mystery of his sudden death. One of the primary sources to this question is a text attributed to one of the royal physicians - Jakub Gosławski. The document, entitled The Death of His Majesty Stephen King of Poland at Grodno on 12 December Anno Domini 1586, better known as The Real Truth about the Illness and Death of Late King Stephen Bathory of Poland, was written soon after the king's death. Its original version has not been found, while two copies have been preserved in the Central Archives of Historical Records in Warsaw and in the Princes Czartoryski Library in Krakow.

The source contains information extremely valuable for historians and historians of medicine about the last days of King Stephen, symptoms of his illness, and treatments meted out to him by his physicians. A valuable supplement is made by a post-mortem report describing the appearance and state of his internal organs. Gosławski's text has already been published in the past, but either it was done without due care, with many mistakes and omissions, or on the basis of some other manuscript, unknown to us. The present edition juxtaposes the two known copies, with a substantial body of editorial commentary and that pertaining to the content. This makes it possible to see the differences between the two copies, in the first place. There is also the first edition of the text included, issued in 1830 by Edward Raczyński, which in the most important fragments is quite different to that of the texts kept in the Central Archives of Historical Records and in the Princes Czartoryski Library.

The edition of this source is even more pertinent given the fact that, in recent years, there is a number of specialists questioning the widespread and preserved diagnosis that the king's death was caused by uraemia. The well-edited source text, with a commentary pertaining to the content, can help researchers in thoroughly analysing the symptoms of Bathory's illness and shed new light on the causes of his death.
\end{abstract}

Nota o Autorze: Agnieszka Pawłowska-Kubik, dr nauk humanistycznych w zakresie historii, asystentka w Zakładzie Historii i Filozofii Nauk Medycznych Gdańskiego Uniwersytetu Medycznego, absolwentka UMK w Toruniu. Zainteresowania badawcze: dzieje polityczne Rzeczypospolitej Obojga Narodów, ze szczególnym uwzględnieniem konfliktów władców ze szlachtą, teoria i praktyka funkcjonowania konstytucji staropolskich, medycyna nowożytna a elity państwa polsko-litewskiego. Stypendystka Polskiej Misji Historycznej w Würzburgu oraz Fundacji Lanckorońskich, wyróżniona w 2015 r. w konkursie „Skomplikowane i proste” pod patronatem Ministerstwa Nauki i Szkolnictwa Wyższego. Publikuje m.in. w „Klio” i „Zapiskach Historycznych”.

Author: Ph.D., assistant at the Department of History \& Philosophy of Medical Sciences, Medical University of Gdańsk, a graduate of the Nicolaus Copernicus University in Torun. Research interests: political history of the Polish-Lithuanian Commonwealth with particular reference to conflicts between the monarchy and the gentry, the theory and practice of functioning of legal acts, modern medicine and elites of the Polish-Lithuanian state. A sholarship holder of the Polish Historical Mission in Würzburg and of the Lanckoroński Foundation, honored in 2015 in the competition "Skomplikowane i proste" under the auspicies of the Ministry of Science and Higher Education. Publishes among others in Klio and Zapiski Historyczne.

Zakład Historii i Filozofii Nauk Medycznych Wydział Nauk o Zdrowiu z Oddziałem Pielęgniarstwa i Instytutem Medycyny Morskiej i Tropikalnej Gdański Uniwersytet Medyczny

ul. Tuwima 15

80-210 Gdańsk

e-mail: apkubik@gumed.edu.pl, agnieszkapawl@wp.pl 


\section{Bibliografia}

\section{Źródła}

Panowanie Henryka Walezyusza i Stefana Batorego królów polskich z rękopisów Albertrandego podtug wydania Ż. Onacewicza. Z dołaczeniem pamiętników historyi Stefana Batorego dotyczących, Kraków 1849, s. 442-444 Prawdziwa sprawa o chorobie i śmierci króla Stefana, w: Pamiętniki do historyi Stefana króla polskiego, wyd. E. Raczyński, Warszawa 1830, s. 143-149

\section{Opracowania}

Giedroyć F., Przyczyna zgonu króla Stefana Batorego, Przegl. Hist., 2, 1906, nr 1, s. 143-156, nr 2, s. 277-290 Grzybowski S., Teki Naruszewicza. „Acta regum et populi Poloni”, Wrocław 1960

Knot A., Dwór lekarski Stefana Batorego, „Archiwum Historii i Filozofii Medycyny oraz Historii Nauk Przyrodniczych", 8, 1928, z. 2, s. 151-207

Marcinkowski T., A New Appraisal of the Death Cause of King Stefan Batory, „Materia Medica Polona”, 23, 1991, nr 3, s. 233-235

Pawiński A., Zgon króla, „Tygodnik Ilustrowany”, 8, 1886, nr 206, s. 371-373

Pragłowski T., Choroby i śmierć króla Stefana Batorego w nowym naświetleniu, „Archiwum Medycyny Sądowej i Kryminologii”, 18, 1968, nr 1, s. 147-159

Walter F., Choroby i zgon króla Stefana Batorego w świetle narady lekarskiej, „Polska Gazeta Lekarska”, 1934, nr 32, s. 595-598, nr 33/34, s. 609-610, nr 35, s. 633-636

Wyrobek E., Jaka była przyczyna tak szybkiej śmierci króla Stefana Batorego, „Ilustrowany Kurier Codzienny”, 16 XII 1929, dodatek: „Kurier Literacko-Naukowy”, s. 1-2 